\title{
Achieving Relational Objectives Through Sponsorship
}

Barbara Caemmerer, ESSCA School of Management, France Raluca Mogos Descotes, Lorraine University, France

\begin{abstract}
With growing awareness of the importance of establishing good relationships with immediate stakeholder groups the scope of sponsorship broadens. Management objectives concerning sponsorship are now often either commercial or relational in nature. As most studies focus on the assessment of the economic effectiveness of sponsorship activities this research investigates how sponsorship can aid in the achievement of a relational objective, specifically the development of citizen commitment towards a public authority. Questionnaire data from 237 spectators of a publicly sponsored sports event were collected and analysed. The findings suggest a rational model of sponsorship effectiveness and support congruence theoretical considerations. The strongest determinants of commitment towards the sponsor are positive attitudes towards the sponsorship activity, the belief that public sponsorship is seen as beneficial for the region. Further, positive attitudes towards the sponsorship depend on whether citizens perceive the sponsorship activity to be a waste of financial resources. This corroborates the idea that sponsorship activities with relational objectives are elaborated on the normative belief whether tax money should be used to sponsor an event. Public sector bodies should also pay attention to explicitly communicate the reasons and benefits of the sponsorship activity in order to enhance perceived event-sponsor congruence. This study explains the dynamics in the sponsorship model that impact on the achievement of relational objectives and identifies managerial implications on how to manage sponsorship activities in a public sector context.
\end{abstract}

Keywords: Sponsorship; Relational Objectives; Services; Public Sector

\section{INTRODUCTION}

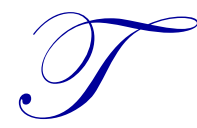

he key objective of this study is to investigate how sponsorship can aid in the achievement of a relational objective, specifically the development of commitment amongst an important stakeholder group towards an organisation. The research is set within the context of organisations dedicating increasingly more financial resources of their communications budget to sponsorship activities (Chien, Cornwell, \& Pappu, 2011; Dalakas \& Levin, 2005; Meenaghan, 1991; Roy \& Cornwell, 2004). This is particularly the case for event-related sponsorship. Indeed, the International Events Group (IEG) reports a steady rise in sponsorship initiatives across the globe. Between 2009 and 2013 global sponsorship expenditures grew from US\$ 44 billion to an estimated US\$ 53.3 billion (IEG, Global Sponsorship Expenditure Report 2013). In contrast to more traditional forms of marketing communications, sponsorship initiatives allow to target specific, homogenous groups of consumers holding common interests (Meenaghan, 2001; Nicholls, Roslow, \& Laskey, 1994).

Through his seminal article "Commercial Sponsorship", Meenaghan (1983) directed the attention of academic scholars to sponsorship as a distinct research domain in the field of marketing, and in particular marketing communications. Gardner and Shuman (1988) define sponsorship activities as investments into events or causes in order to reach broad organisational objectives. Primarily, organisations use sponsorship activities to achieve commercial targets (Cliffe \& Motion, 2005; Cornwell, Humphreys, Maguire, Weeks, \& Tellegen, 2006; Herrmann, Walliser, \& Kacha, 2011; Jagre, Watson, \& Watson, 2001). However, with growing awareness of the importance of establishing good relationships with immediate stakeholder groups (Ferrell \& Ferrell, 2008), the scope of sponsorship broadens. Management objectives concerning sponsorship may now often be either commercial (such 
as increased brand awareness, image and profit) or relational in nature (such as the establishment of commitment, goodwill and improved community relations) (Dean, 2002; Farrelly \& Quester, 2003; Lacey, Close, \& Finney, 2010; Madill \& O'Reilly, 2010; Zdravkovic \& Till, 2012). Despite this recognition, the majority of studies in this field of research focus on the assessment of the economic effectiveness of sponsorship activities (Gwinner, 1997; Pope, Voges, \& Brown, 2009).

In order to address the objective of this study, the research focuses on a sponsorship initiative in a public sector context and its impact on citizens' commitment towards the sponsoring body. Conducting this study in a public sector context presents an ideal opportunity to assess sponsorship effectiveness in the achievement of pure relational objectives without a hidden commercial agenda. Further, a need for such an investigation arises from the fact that public sector bodies increasingly invest resources into the support of events like concerts and sports events (Walliser, 2006) in order to establish and maintain good relations with their electorate (Matthews \& Shulman, 2005; McNulty \& Ferlie, 2004; Osborne \& Gaebler, 1992; Sanger, 2008). One of the reasons for this is that the adoption of private sector marketing initiatives, such as event sponsoring, is now a socially accepted form of organisational behaviour in public sector contexts. In fact, taking a closer look at events at a local, regional or national level reveals that the majority of these benefit from public sector sponsorship. Despite this development, public sector organisations are practically neglected in the sponsorship literature (Walliser, 2006). The few studies that have investigated sponsorship activities in the public sector have, in the main, focused on citizen perceptions of public sector bodies being sponsored by private companies, in order to enhance revenue and attract attention (e.g. McCarville \& Copeland, 1994; Mowen, Kyle, \& Jackowski, 2007). However, our research is concerned with the question how sponsorship activities of public bodies impact citizen perceptions. In other words, we contribute to extant theory by looking at the phenomenon from the perspective of the public body as the sponsor, not the sponsored entity.

The following section outlines the theoretical framework of the study, discussing how event sponsorship may impact on the formation of commitment.

\section{THEORETICAL FRAMEWORK AND DEVELOPMENT OF RESEARCH HYPOTHESES}

\section{Commitment Towards The Sponsor}

The commitment construct has its origins in the human resource literature (Porter, Steers, Mowday, \& Boulian, 1974). Early studies into this phenomenon establish that commitment includes an individual's acceptance of the organisation, involvement in what the organisation does, the willingness to exert effort for the organisation, as well as loyalty (Hall, 1979). These findings are supported in later studies (e.g. Donavan, Brown, \& Mowen, 2004).

With a general recognition in the wider management literature over the last three decades that organisations need to adopt a more external orientation, an understanding of how commitment amongst other important stakeholder groups outside the organisation can be established is of interest. In particular, the relationship and services marketing literature contribute important insights into this phenomenon (e.g. Grönroos, 1989; Heskett, Jones, Loveman, Sasser, \& Schlesinger, 1994). For example, customer commitment towards an organisation may have a positive link to long-term organisational success (Gustafsson, Johnson, \& Roos, 2005; White \& Schneider, 2000). However, in marketing terms, commitment reflects consumers' stability and depth of the relational bond they establish with an organisation, its products or services, and their propensity to defend and support the respective entity (Bansal, Irving, \& Taylor 2005; Fullerton, 2003). Therefore, commitment is a relational objective, as suggested by Lacey et al. (2010) or Madill and O’Reilly (2010).

Further, establishing commitment amongst important stakeholders enhances organisational legitimacy. Organisational legitimacy is associated with terms such as acceptance, appropriateness, and congruence (Deephouse $\&$ Carter, 2005). The literature suggests that organisations with stronger legitimacy extract scarce resources from the environment more easily, and survive longer (Hillebrand, Nijholt, \& Nijssen, 2011; Meyer \& Rowan, 1977; Suddaby \& Greenwood, 2005). As this is only possible through a social consensus of committed groups that believe the organisation is worthy of support, this study focuses specifically on the establishment of citizen commitment towards local public sector bodies through the use of sponsorship initiatives (Lacey et al,. 2010). To conclude, in 
line with the above literature, citizen commitment is a relational objective that includes citizens' bond with as well as their acceptance and support of a public sector body. While the majority of studies in the sponsorship literature has investigated the impact of sponsorship activity on consumer commitment towards the sponsored entity (e.g. Hattula, Hammerschmidt, Hattula, \& Bauer, 2011), we assess its effect on commitment towards the sponsor.

\section{Involvement With The Sponsored Entity And Positive Attitudes Towards The Sponsorship Activity}

The sponsorship literature suggests that an image transfer from the sponsored entity to the sponsor occurs, as consumers' personal liking of the sponsored entity is balanced with their attitudes towards the sponsor. Consumers' emotional involvement in and identification with the event impact perceptions of the sponsorship activity as well as the sponsor (Cornwell \& Coote, 2005; Madrigal, 2001; Ngan Prendergast, \& Tsang, 2011; Sirgy, Lee, Johar, \& Tidwell, 2008). Therefore, with regards to public service contexts, involvement with the sponsored sport event will positively contribute to citizens' commitment towards the public sector sponsor. Similarly, involvement with the event will also lead to positive attitudes towards the sponsorship activity. Thus:

H1a: Involvement with the event will be positively related to commitment to the sponsor.

H1b: Involvement with the event will be positively related to positive attitudes towards the sponsorship activity.

These positive attitudes are transferred to the sponsor (Dalakas \& Levin 2005;

Meenaghan 2001), suggesting higher levels of sponsor acceptance amongst the audience. Therefore, with regards to public service contexts, positive perceptions towards the event will positively contribute to the commitment towards the sponsor. Hence:

H2: Positive attitudes towards the sponsorship activity will be positively related to commitment to the sponsor.

\section{Negative Attitudes Towards The Sponsorship Activity}

On the other hand, negative attitudes towards the sponsorship activity could manifest themselves in the idea that the initiative is a waste of financial resources. This may be particularly the case in public sector contexts, as citizens believe to have a financial stake in public service organisations and their actions through the payment of taxes. The public administration literature suggests that public sector bodies are often rationally judged by their input into activities, rather than the output, as the final outcome of their actions is difficult to assess (Kearsy \& Varey, 1998). However, more positive attitudes towards the sponsored event should decrease perceptions of financial waste, as the sponsorship activity is more likely to be perceived as being worthwhile:

H3: Positive attitudes towards the event will be negatively related to perceptions that the sponsorship activity is a waste of financial resources.

On the other hand, in the context of a sponsorship initiative with no obvious commercial objectives, the suspicion could arise that providing the event with resources is an inequitable exchange for the organisation in the absence of commercial benefits (Dean, 2002). Thus, in the case of public sector organisations sponsoring a sport event, citizens may attribute the sponsorship activity to a hidden motive, such as a particular political agenda. This could lead to perceptions that the sponsorship activity is indeed a waste of financial resources, which will negatively impact on positive attitudes towards the sponsorship activity:

H4a: Perceptions that the sponsorship activity is a waste of financial resources will be negatively related to positive attitudes towards the sponsorship activity.

Following on from the idea that positive attitudes towards a sponsorship activity impact positively on commitment towards the sponsor (Dalakas \& Levin 2005; Meenaghan 2001), it is possible that - inversely negative perceptions of a sponsorship activity will have a negative impact on commitment to the sponsor. Therefore:

H4b: Perceptions that the sponsorship activity is a waste of financial resources will be negatively related to commitment to the sponsor. 


\section{Event-Sponsor Congruence}

Several authors suggest that the congruence between the sponsored entity and the sponsor is a critical factors in the effectiveness of sponsorship (Cornwell et al., 2006; Simmons \& Becker-Olsen, 2006; Sohn \& Han, 2012; Olson \& Thjømøe, 2011; Woisetschlaeger \& Michaelis, 2012). Coppetti, Wentzel, Tomczak, and Henkel (2009) highlight that congruence refers to consumers' perceptions of similarity between the sponsor and the sponsored endorser or event. Meenaghan (2001) argues that in order to perceive congruence, consumers must be able to make a logical and rational connection between the two elements. They can establish these connections on different grounds, including relevance, functionality, attributes or image (Rifon, Choi, Trimble, \& Li, 2004). Speed and Thompson (2000) suggest regarding congruence as a uni-dimensional construct to assess the fit between the sponsor and the sponsored entity in general, without restrictions relating to the grounds of the match.

Evidence suggests that the perceived general match between event and sponsor can lead to more favourable outcomes in general, whereas a perceived mismatch could have even negative consequences (Olson \& Thjømøe, 2011). For example, congruence enhances brand equity and attitudes towards the sponsor (Simmons \& BeckerOlsen, 2006), whereas the opposite may be the case when perceptions of congruence are low. According to Jagre et al. (2001) low levels of congruence may lead to greater elaboration, which in turn lead to stronger resistance to positive sponsorship messages and higher levels of scepticism about the sponsorship motive. On the other hand, stronger congruence is related to greater perceptions of harmony and thus more positive attitudes towards the sponsorship activity as well as the sponsor in general. More recently, Filis and Spais (2012) could further show in a study of sport event sponsorship that repeat exposure to sponsorship messages strengthened perceived event-sponsor congruence. They also found that personality congruence between event and sponsor has the strongest impact on attitudes towards the sponsoring brand. Team performance - whether positive or negative - impacted perceptions of brand quality, but not those of corporate image.

With regard to the public sector context, the assessment of congruence between event sponsorship initiative and the organisation is particularly interesting. Some organisations have less of a logical or natural link with potential sponsored entities than others (such as sports equipment manufacturers with sport events) (Cornwell et al., 2006). Clearly, public sector organisations have less such links, particularly not in commercial terms, and may thus need to stress other shared grounds such as health improvement or regional development that serve the wider population (Matthews \& Shulman, 2005) when sponsoring events. As such, assessing the extent to which perceived congruence can be achieved is interesting in this context, as well as if potential congruence impacts on attitudes towards the sponsorship, and commitment amongst citizens. The review of the extant literature leads to the following hypotheses:

H5a: The level of perceived congruence between the event and the sponsor is positively related to commitment to the sponsor.

H5b: The level of perceived congruence between the event and the sponsor is negatively related to perceptions that the sponsorship activity is a waste of financial resources.

H5c: The level of perceived congruence between the event and the sponsor is positively related to positive attitudes towards the sponsorship activity.

For an overview of the conceptual model please refer to Figure 1. 


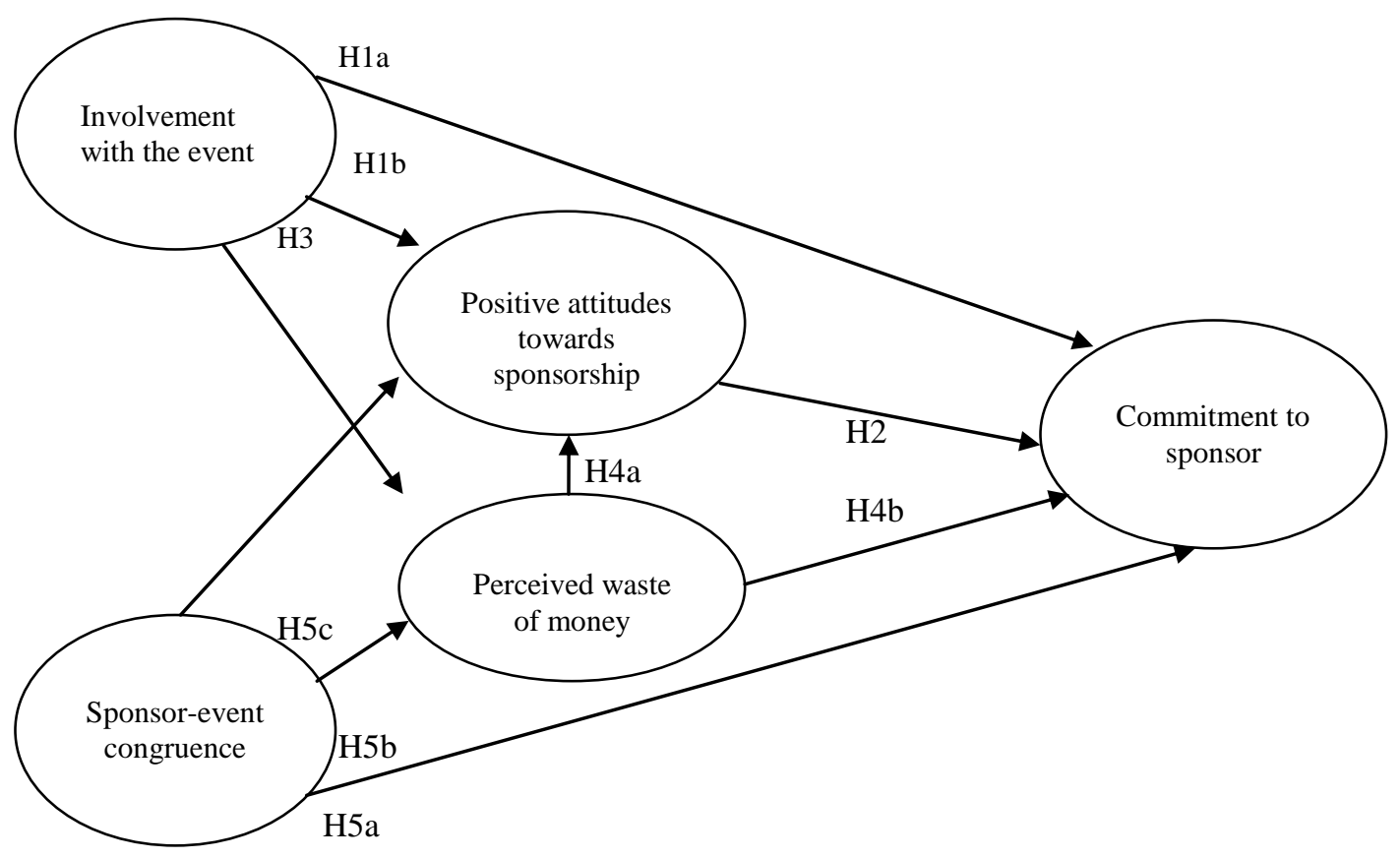

Figure 1: Conceptual Model

\section{METHODOLOGY}

The nature of the research objective lent itself to a quantitative methodology. Using a pre-tested questionnaire, 300 spectators of the finals of the French National League Handball Cup were surveyed. This important national sport event has been running for ten years. On an annual basis about 30,000 tickets are sold for the nineteen games played. Every year the event is hosted by a different city. The year of the study the Cup was held in Nantes and was heavily sponsored by Nantes City Council. Even though the Cup is a national event, most of the spectators come from the city and the region where the event is hosted. The event attracts news coverage in both, national and regional media.

The questionnaire assessed respondents' attitudes towards the event, perceived congruence between the event and the City Council, positive attitudes towards the sponsorship activity, the perception of the sponsorship activity as a waste of money, and commitment towards the Council. The survey took place on site and yielded a total of 237 usable questionnaires from Nantes citizens.

\section{Measures}

Citizen commitment was measured by using a scale specifically developed for public sector contexts with sound psychometric properties (Sabadie, 2003). In line with the majority of publications in this field (Bansal, Irving, \& Taylor, 2004) the scale treats the construct as uni-dimensional (Hennig-Thurau, Gwinner, \& Gremler, 2002; Sharma \& Patterson, 2000).

Involvement with the event were assessed through the involvement scale used by Voss, Spangenberg, and Grohmann (2003), adapted from the Consumer Involvement Profile scale of Kapferer and Laurent (1993). Previous research shows that most of the spectators attending an event are residents of the region where the event is held (Walliser, Mathieu, \& Mogos Descotes, 2005). Their interest in the event is frequently motivated by the support of their regional team as well as their interest in the particular sport. The scale used has the advantage to capture both: participants' involvement with their team as well as their interest in the sport, in this case handball. 
Overall sponsor-event congruence was captured using the scale by Rifon et al. (2004) to assess the perceived fit of the City Council as a sponsor for the Cup. Recent research demonstrates the relevance for using an overall sponsor-event congruence measure to assess the effectiveness of a sponsorship activity (Cornwell, Weeks, \& Roy, 2005; Cornwell et al., 2006; Simmons \& Becker-Olsen, 2006; Olson, 2010; Olson \& Thjømøe, 2011). In addition, different dimensions of the sponsor-event congruence such as geographic and audience similarity are strong predictors of overall sponsor-event congruence (Olson \& Thjømøe, 2011). These findings justify the measurement of overall congruence, rather than its several dimensions.

In line with Walliser et al. (2005), attitudes towards the public authority's sponsorship was conceptualized as a bi-dimensional construct consisting of the dimensions 1) positive attitude towards public authorities' sponsorship and 2) perceived waste of money. This is the only published scale to specifically assess attitudes towards sponsorship activities of public sector bodies. For a detailed overview of the measurement scales refer to Table 1. Note that all items were assessed on a 7-point Likert scale, if not indicated otherwise.

\section{RESEARCH RESULTS}

\section{Sample Characteristics And Descriptive Statistics}

The age of the respondents ranges between 14 and 79 years old with an average about 40 (mean $=38.85$; standard deviation $=18.89$; median $=36$; mode $=20$ ). 177 of the interviewees were male and 60 female and all interviewees had previous service experiences with the City Council and live in the city of Nantes.

Table I presents the structure and scores of the different attitudinal measures used in our questionnaire. All items were assessed on a 7-point Likert scale, if not indicated otherwise.

The respondents have rather positive attitudes towards the City Hall's sponsorship activity, average scores ranging from 5.13 to 5.51. Respondents tend as well to agree that the sponsorship activity of the City Hall of Nantes is not a waste of money (mean $=2.8$ for the negative items) and the congruence between the event and the sponsor is seen as rather high. The mean scores for the three congruence items range from 4.88 to 5.19, suggesting that Nantes citizens believe it is appropriate for a public sponsor to financially support sport events.

This may be at least partly explained by the fact that the interviewed spectators were highly interested in the event (mean $=5.82$ ) and they tended to highly evaluate their interest towards the Handball club of Nantes (mean $=5.76)$.

Finally, the commitment level towards the City Hall of Nantes with mean scores ranging from 4.77 to 4.81 suggests that the citizens of Nantes developed a rather positive relationship with their City Hall.

\section{Comparison Among Independent Groups}

Socio-demographic variables (age and gender) potentially having an influence on sponsorship effectiveness were controlled for.

The non-parametric Mann-Whitney test reveals that no significant difference exists between women and men regarding the appreciation of the five latent constructs of interest in our questionnaire: commitment and positive attitude towards the sponsorship activities of the public sponsor, perceived waste of financial resources, involvement with the event and the perceived congruence between the public sponsor and the event.

On the other hand, non-parametric Kendall correlations between respondents' age and the five latent constructs reveal a single significant and negative correlation between the age of the respondents and the perceived level of congruence between the public sponsor and the event (Kendall's Tau $=-0.094, p<0.05$ ). This result suggests that the older the spectators are, the less they believe that the association between the public sponsor and the sport event is compatible. 


\section{Reliability Analysis For Dimensions And Items}

PLS path modelling (PLSPM) was used for the testing of the research hypotheses and the assessment of the psychometric properties of the measurement instruments (Chin, 1998; Fornell \& Bookstein, 1982). PLS was preferred to LISREL because PLS is known to be particularly advantageous when the sample size is reduced (Fornell \& Bookstein, 1982). Moreover, according to Fornell and Larcker (1981), the PLS method is also more robust than LISREL in the sense that it does not require normally distributed data. The results of the KolmogorovSmirnov and Shapiro-Wilk normality tests are displayed in Table I. They reveal that the data is not normally distributed: the Kolmogorov-Smirnov statistic varies between 0.13 and 0.24 ( $p<0.001$ for all the items), while all the Shapiro-Wilk's Ws computed for the items are significantly lower than the cut-off value of 1.00 ( $p<0.001$ for all the items). PLS is also more commonly used in the early stages of research in a field. From a theoretical perspective, to the best of our knowledge our study is the first to explore and test the link between citizens' attitudes towards the sponsorship of professional sport events and their commitment to public sponsors.

PLSPM supports the assessment of psychometric properties of measurement instruments including reliability, convergent validity and discriminant validity (Chin, 1998; Fornell \& Larcker, 1981).

Composite reliability was assessed by examining the Joreskog's Rhôs and Cronbach's Alphas, all exceeding the cut-off value of 0.7 , with one exception, namely the Cronbach's Alpha for the "involvement with the event" measure. For this latent construct the Joreskog's Rhô reaches the value of 0.83 , while the Cronbach's Alpha equals 0.59. Roussel, Durrieu Campoy, and El Akremi (2001) observe that Cronbach's Alpha values are highly influenced by the number of items composing a latent contruct: the more items are used to capture a latent construct, the higher the Cronbach's Alphas values are. For this reason, the authors suggest that the Joreskog's Rhô represents a more accurate indication regarding composite reliability for the measures composed by a reduced number of items. Note that the measure "involvement with the event" is solely composed of two items (the minimum number of items for a latent construct). Therefore, based on the highly satisfying value of the Joreskog's Rhô for this measure (0.83), we conclude that its composite reliability is acceptable. 
Table I: Measures, Descriptive Statistics And The Results Of The One-Sample Kolmorogov -Smirnov Test $(\mathrm{N}=237)$

\begin{tabular}{|c|c|c|c|c|c|c|c|}
\hline Construct and references & $\begin{array}{l}\text { Items } \\
\text { (measured on Likert } 7 \text {-point scales ranging from } 1 \\
=\text { completely disagree to } 7=\text { completely agree) }\end{array}$ & Mean & $\begin{array}{c}\text { Std. } \\
\text { deviation }\end{array}$ & Median & Mode & $\begin{array}{c}\text { Kolmorogov - } \\
\text { Smirnov Test } \\
\text { Statistic And P-Value }\end{array}$ & $\begin{array}{l}\text { Shapiro Wilk } \\
\text { Statistic And P-Value }\end{array}$ \\
\hline \multirow{4}{*}{$\begin{array}{l}\text { Relational objective: } \\
\text { Commitment to the sponsor } \\
\text { (adapted from Sabadie 2003) }\end{array}$} & $\begin{array}{l}\text { I talk about the City Council as an excellent service } \\
\text { provider.(C1) }\end{array}$ & 4.810 & 1.524 & 5.000 & 5.000 & $0.178 ; \mathrm{p}<0.001$ & $0.921 ; \mathrm{p}<0.001$ \\
\hline & I tend to praise and defend the City Council.(C2) & 4.814 & 1.464 & 5.000 & 5.000 & $0.162 ; \mathrm{p}<0.001$ & $0.931 ; p<0.001$ \\
\hline & $\begin{array}{l}\text { I think of continuing a long time to appreciate the } \\
\text { current City Council.(C3) }\end{array}$ & 4.767 & 1.493 & 5.000 & 5.000 & $0.174 ; \mathrm{p}<0.001$ & $0.931 ; \mathrm{p}<0.001$ \\
\hline & $\begin{array}{l}\text { I will recommend City Council services to my } \\
\text { friends (in case there are private alternatives). (C4) }\end{array}$ & 4.789 & 1.525 & 5.000 & 4.000 & $0.132 ; \mathrm{p}<0.001$ & $0.935 ; \mathrm{p}<0.001$ \\
\hline \multirow{2}{*}{$\begin{array}{l}\text { Involvement with the event } \\
\text { (adapted from Voss et al. 2003) }\end{array}$} & This sport event interests me a lot.(IEV1) & 5.819 & 1.060 & 6.000 & 6.000 & $0.214 ; \mathrm{p}<0.001$ & $0.826 ; p<0.001$ \\
\hline & $\begin{array}{l}\text { I grant much importance to our city's sport club. } \\
\text { (IEV2) }\end{array}$ & 5.755 & .088 & 6.000 & 6.000 & $0.197 ; \mathrm{p}<0.001$ & $0.818 ; \mathrm{p}<0.001$ \\
\hline \multirow[t]{4}{*}{$\begin{array}{l}\text { Sponsor-event congruence } \\
\text { (Rifon } \text { et al. 2004) }\end{array}$} & $\begin{array}{l}\text { According to you the support of this sport event by } \\
\text { the City Council is: }\end{array}$ & & & & & & \\
\hline & Not compatible (1)----- (7) Compatible (FIT1) & 4.882 & 1.519 & 3.000 & 6.000 & $0.189 ; \mathrm{p}<0.001$ & $0.917 ; \mathrm{p}<0.001$ \\
\hline & Not congruent (1)----- (7) Congruent (FIT2) & 4.878 & 1.486 & 2.000 & 4.000 & $0.146 ; \mathrm{p}<0.001$ & $0.933 ; \mathrm{p}<0.001$ \\
\hline & Not a good fit (1)----- (7) Good fit (FIT3) & 5.186 & 1.440 & 3.000 & 6.000 & $0.199 ; \mathrm{p}<0.001$ & $0.905 ; \mathrm{p}<0.001$ \\
\hline \multirow{5}{*}{$\begin{array}{l}\text { Positive attitude towards the } \\
\text { sponsorship activity } \\
\text { (Walliser } \text { et al. 2005) }\end{array}$} & $\begin{array}{l}\text { I like the presence of the City Council at this sport } \\
\text { event. (PA1) }\end{array}$ & 5.135 & 1.224 & 5.000 & 5.000 & $0.186 ; \mathrm{p}<0.001$ & $0.921 ; \mathrm{p}<0.001$ \\
\hline & $\begin{array}{l}\text { Sponsoring this sport event improves the image of } \\
\text { the City Council. (PA2) }\end{array}$ & 5.148 & 1.227 & 5.000 & 5.000 & $0.186 ; \mathrm{p}<0.001$ & $0.909 ; \mathrm{p}<0.001$ \\
\hline & $\begin{array}{l}\text { The presence of the City Council at this sport event } \\
\text { gives extra value to the region. (PA3) }\end{array}$ & 5.127 & 1.279 & 5.000 & 5.000 & $0.207 ; \mathrm{p}<0.001$ & $0.914 ; \mathrm{p}<0.001$ \\
\hline & $\begin{array}{l}\text { The sponsorship by the City Council makes people } \\
\text { talk about the region. (PA4) }\end{array}$ & 5.190 & 1.372 & 5.000 & 5.000 & $0.195 ; \mathrm{p}<0.001$ & $0.905 ; \mathrm{p}<0.001$ \\
\hline & $\begin{array}{l}\text { It is nice to live in a city which sponsors sport } \\
\text { events (PA5). }\end{array}$ & 5.511 & 1.202 & 6.000 & 6.000 & $0.236 ; \mathrm{p}<0.001$ & $0.879 ; \mathrm{p}<0.001$ \\
\hline \multirow{3}{*}{$\begin{array}{l}\text { Negative attitudes towards the } \\
\text { sponsorship activity: } \\
\text { Perceived waste of money } \\
\text { (Walliser } \text { et al. 2005) }\end{array}$} & $\begin{array}{l}\text { The sponsorship of this sport event by the City } \\
\text { Council is a waste of money.(PWM1) }\end{array}$ & 2.895 & 1.390 & 3.000 & 2.000 & $0.187 ; \mathrm{p}<0.001$ & $0.918 ; \mathrm{p}<0.001$ \\
\hline & $\begin{array}{l}\text { It is not the role of public authorities to sponsor } \\
\text { professional sports events. (PWM2) }\end{array}$ & 2.730 & 1.403 & 2.000 & 2.000 & $0.205 ; \mathrm{p}<0.001$ & $0.896 ; \mathrm{p}<0.001$ \\
\hline & $\begin{array}{l}\text { Tax money should not be used to sponsor a } \\
\text { professional sport event. (PWM3) }\end{array}$ & 2.857 & 1.424 & 3.000 & 2.000 & $0.186 ; \mathrm{p}<0.001$ & $0.916 ; \mathrm{p}<0.001$ \\
\hline
\end{tabular}


In order to assess potential auto-correlation issues among the items composing the latent constructs, the inter-item correlation matrixes for each measurement scale should be inspected. In the case of this study, no autocorrelation problems can be observed since none of the Pearson correlation coefficients is higher than the critical value of 0.7 (Roussel et al., 2001). Indeed, the highest observed Pearson correlation coefficients exists between the items C2 and C3 (Pearson correlations coefficient $=0.69, \mathrm{p}<0.001$ ), and suggests that the two items share less than $50 \%$ of common variance. Therefore, no auto correlation problems exist for the items composing our measurement scales.

Convergent validity was checked for by assessing the loadings of items on their respective factors, which all exceeded the cut-off value of 0.7 suggested by Nunally and Bernstein (1994) with one exception. More precisely, the item IEV2: "I grant much importance to our city's sport club", is characterized by a slightly lower loading than $0.7(\lambda=0.61)$ on the latent construct "involvement with the event". However, Wold (1980) suggests that loadings higher than 0.5 are acceptable, and therefore we considered this loading as not being problematic.

Finally, discriminant validity was assessed by examining whether each construct shared more variance with its measures than with other constructs in the model (Barclay, Higgins \& Thompson, 1995; Chin, 1998). The average variance extracted (AVE) should be higher than the squared correlation of any two latent variables (LV) in the model. The results suggest that this condition is fulfilled. Tables II and III summarize the analysis results discussed above.

\section{Correlation And Regression Analysis}

Before testing our research hypotheses we tested for eventual collinearity and autocorrelation issues between constructs. First, on a descriptive basis, we examined Kendall's tau non-parametrical correlation between the five latent variables in our model. The highest correlation can be observed between the constructs perceived waste of money and positive attitude towards the public sponsor (Kendall's Tau coefficient $=-0.56, p<0.001$ ). The magnitude of this correlation suggests that there are no collinearity and autocorrelation problems between constructs (Roussel et al., 2001).

Further, VIF (Variance Inflation Factor) and the Durbin-Watson test were performed. For the DurbinWatson test, we estimated with SPSS 22.00 the linear regression of commitment towards the public sponsor (dependent variable) as a function of the four other latent variables in the research model, namely perceived congruence between the public sponsor and the event, positive attitude, perceived waste of money and involvement with the event. The observed VIF for our latent variables range between 1.059 for "involvement with the event" and 2.911 for "perceived waste of money". This is below the recommended cut-off of 5.000, which suggests that multicollineriaty is not an issue (Grewal, Cote, \& Baumgartner, 2004).

Furthermore, the Durbin-Watson Statistic was used to test for the independence of studentized residuals. The value of the Durbin-Watson statistic ranges from 0 to 4 . It is suggested that the residuals are uncorrelated if the Durbin-Watson statistic is between 1.5 and 2.5 (Garson, 2012). In this case, the value of Durbin-Waston is 1.718, indicating no serial correlation. Moreover the VIF indexes are all lower than the critical value of 5 . Therefore, there are no collinearity and autocorrelation problems detected for the dependent variables. 
Table II: Constructs, Items, Standardized Loadings, Composite Reliability, And Average Variance (N = 237 Citizens)

\begin{tabular}{|c|c|c|c|c|}
\hline Construct and references & $\begin{array}{l}\text { Items } \\
\text { (measured on Likert 7-point scales ranging from } \\
1=\text { completely disagree to } 7=\text { completely agree) }\end{array}$ & $\begin{array}{l}\text { Standardized loadings/ } \\
\text { weights }\end{array}$ & $\begin{array}{l}\text { Composite reliability } \\
\text { Joreskog's Rhô and } \\
\text { Cronbach's Alpha }\end{array}$ & $\begin{array}{l}\text { Average variance } \\
\text { extracted }\end{array}$ \\
\hline $\begin{array}{l}\text { Relational objective: } \\
\text { Commitment to the sponsor } \\
\text { (adapted from Sabadie 2003) }\end{array}$ & $\begin{array}{l}\text { I talk about the City Council as an excellent service } \\
\text { provider.(C1) } \\
\text { I tend to praise and defend the City Council.(C2) } \\
\text { I think of continuing a long time to appreciate the current City } \\
\text { Council.(C3) } \\
\text { I will recommend City Council services to my friends (in case } \\
\text { there are private alternatives). (C4) }\end{array}$ & $\begin{array}{l}0.822 \\
0.879 \\
0.850 \\
0.840\end{array}$ & $0.911 ; 0.869$ & 0.719 \\
\hline $\begin{array}{l}\text { Involvement with the event } \\
\text { (adapted from Voss et al., 2003) }\end{array}$ & $\begin{array}{l}\text { This sport event interests me a lot.(IEV1) } \\
\text { I grant much importance to our city's sport club. (IEV2) }\end{array}$ & $\begin{array}{l}0.922 \\
0.612 \\
\end{array}$ & $0.832 ; 0.595$ & 0.663 \\
\hline $\begin{array}{l}\text { Sponsor-event congruence } \\
\text { (Rifon et al., 2004) }\end{array}$ & $\begin{array}{l}\text { According to you the support of this sport event by the City } \\
\text { Council is: } \\
\text { Not compatible (1)----- (7) Compatible (FIT1) } \\
\text { Not congruent (1)----- (7) Congruent (FIT2) } \\
\text { Not a good fit (1)---- (7) Good fit (FIT3) }\end{array}$ & $\begin{array}{l}0.797 \\
0.886 \\
0.806\end{array}$ & $0.871 ; 0.776$ & 0.690 \\
\hline $\begin{array}{l}\text { Positive attitude towards the } \\
\text { sponsorship activity } \\
\text { (Walliser et al., 2005) }\end{array}$ & $\begin{array}{l}\text { I like the presence of the City Council at this sport event. (PA1) } \\
\text { Sponsoring this sport event improves the image of the City } \\
\text { Council. (PA2) } \\
\text { The presence of the City Council at this sport event gives extra } \\
\text { value to the region. (PA3) } \\
\text { The sponsorship by the City Council makes people talk about } \\
\text { the region (PA4). } \\
\text { It is nice to live in a city which sponsors sport events (PA5). }\end{array}$ & $\begin{array}{l}0.821 \\
0.803 \\
0.783 \\
0.819 \\
0.771\end{array}$ & $0.904 ; 0.868$ & 0.654 \\
\hline $\begin{array}{l}\text { Negative attitudes towards the } \\
\text { sponsorship activity: } \\
\text { Perceived waste of money } \\
\text { (Walliser et al., 2005) }\end{array}$ & $\begin{array}{l}\text { The sponsorship of this sport event by the City Council is a } \\
\text { waste of money.(PWM1) } \\
\text { It is not the role of public authorities to sponsor professional } \\
\text { sports events. (PWM2) } \\
\text { Tax money should not be used to sponsor a professional sport } \\
\text { event. (PWM3) }\end{array}$ & $\begin{array}{l}0.859 \\
0.883 \\
0.845\end{array}$ & $0.897 ; 0.828$ & 0.744 \\
\hline
\end{tabular}


Table III: Discriminant Validity Assessment ( $\mathrm{n}=237$ Citizens)

\begin{tabular}{llllll}
\hline $\begin{array}{l}\text { Squared Correlation } \\
\text { Between The Latent Variables }\end{array}$ & Involvement & Congruence & $\begin{array}{l}\text { Positive } \\
\text { Attitude }\end{array}$ & $\begin{array}{l}\text { Perceived Waste } \\
\text { Of Money }\end{array}$ & Commitment \\
\hline Involvement & $\mathbf{1}$ & & & & \\
Congruence & 0.001 & $\mathbf{1}$ & & & \\
Positive attitude & 0.040 & 0.005 & $\mathbf{1}$ & & \\
Perceived waste of money & 0.050 & 0.019 & 0.647 & $\mathbf{1}$ & $\mathbf{1}$ \\
Commitment & 0.010 & 0.063 & 0.184 & 0.114 & 0.719 \\
\hline Mean Communalities (AVE) & 0.663 & 0.690 & 0.744 & 0.654 & \\
\hline
\end{tabular}

\section{Summary Of Research Results And Interpretation: Hypotheses Testing}

As can be seen in Figure 2, five out of nine hypotheses find empirical support. As expected, citizens' involvement with the event reinforces their belief that public sponsorship activities are not a waste of financial resources $(\beta=-0.228 ; \mathrm{t}=-3.610 ; p<0.001)(\mathrm{H} 3)$. Moreover, the perceived fit between the event and the public sponsor diminishes citizens' negative perceptions that sponsoring sport events represent a waste of money or that tax money should not be allocated to the support of such purposes $(\beta=-0.146 ; \mathrm{t}=-2.323 ; p<0.05)(\mathrm{H} 5 \mathrm{~b})$. Furthermore, the belief that the sponsorship of a sports event is a perceived waste of financial resources reduces strongly the formation of a positive attitude towards the sponsorship activity $(\beta=-0.806 ; \mathrm{t}=-20.007 ; p<0.001)$ (H4a).

Research hypotheses H1b and H5c do not find empirical support: Citizen involvement with the event, as well as perceptions of sponsor-event congruence have no direct impact on positive attitude towards the sponsorship activity. Nevertheless, both have an indirect impact on the formation of positive attitudes towards the sponsorship activity, which is mediated by a perceived waste of financial resources $(\beta=0.183 ; \mathrm{p}<0.05$ for involvement with the event; $\beta=0.118 ; p<0.05$ for congruence). Thus, in line with the effect sizes for $\mathrm{R}^{2}$ (small 0.02 , medium 0.13 , large 0.26) proposed by Cohen (1988), the following can be concluded: perceived sponsor-event congruence and the involvement with the event have a moderate indirect impact on citizens' positive attitudes towards the sponsorship activity.

Furthermore, commitment to the sponsor is highly and directly enhanced by citizens' positive attitudes towards the sponsorship $(\beta=0.473 ; \mathrm{t}=4.877 ; p<0.001)(\mathrm{H} 2)$, and by perceived sponsor-event congruence $(\beta=$ $0.229 ; \mathrm{t}=3.942 ; p<0.001)(\mathrm{H} 5 \mathrm{a})$. Perceived waste of financial resources has a non-significant direct impact on commitment to the sponsor (H4b). However, in line with the effect sizes for $\mathrm{R}^{2}$ (small 0.02, medium 0.13, large 0.26) proposed by Cohen (1988), the indirect impact of perceived waste of financial resources is strong through the negative impact it has on citizens' positive attitude towards the sponsorship activity $(\beta=-0.381 ; p<0.001)$. Finally, the direct impact of citizens' involvement with the event has no direct impact on their commitment to the sponsor (H1a), and its indirect impact is negligible as well.

It is worth noting that the change statistics suggest that no differences in the explanatory power of our regression models composing the research model can be achieved based on variations regarding the influence paths among the independent variables (Sig F change $=0.000$ ). The same observation can be made for all the other regression models obtained through the PLSPM estimations: positive attitude towards the public sponsor (dependent variable) as a function of perceived waste of money, perceived fit between the public sponsor and the event (independent variables - the latter two), perceived waste of money (dependent variable) as a function of perceived fit between the public sponsor and the event (independent variables). These results suggest that no better alternative research model, composed by the five latent variables we used in our study design can be envisaged.

Finally, model assessment in PLS is based on the evaluation of the quality of the predictive relationships in the model (the explained and adjusted $\mathrm{R}^{2}$ ) and the quality of the measurement model, which is mainly reflected by the AVE for LVs and redundancy estimation. Four GoF (goodness of fit) indexes were developed in PLS path modelling to assess the quality of the research model (Tenenhaus, Vinzi, Chatelin, \& Lauro, 2005). The first GoF index called Outer Model GoF index evaluates the quality of the measurement model, mainly based on the communalities of the LVs (AVEs in PLS path modelling). The critical value for this index is 0.9. A second GoF index, called the Inner Model GoF index, assesses the quality of the predictions in the research model based on the 
$\mathrm{R}^{2}$ of the endogenous latent variables (performance of the structural model). The critical value for this index is 0.9. Third, the Relative GoF index is obtained by dividing the absolute value by its maximum value achievable for the analysed dataset through bootstrap estimations. The critical value for this index is also 0.9. Finally, the absolute GoF index reflects the overall quality of both measurement and prediction models. It is calculated as the product of the Outer Model GoF index and the Inner Model GoF index. The Absolute GoF index is the most widely used GoF index and in line with the effect sizes for $\mathrm{R}^{2}$ (small 0.02, medium 0.13, large 0.26) proposed by Cohen (1988), Antioco, Moenaert, Feinberg, and Wetzels (2008) derived the GoF criteria for small, medium, and large effect sizes of $\mathrm{R}^{2}$ equaling $0.1,0.25$, and 0.36 . Accordingly, the Absolute GoF index for the model of this study (Absolute GoF $=0.470$ ) can be considered as satisfying. The same holds for the Relative, Outer and Inner Model Indexes, which all exceed the cut-off value of 0.9 (Relative $\mathrm{GoF}=0.930$; Outer Model GoF = 0.991; Inner Model GoF = 0.939).

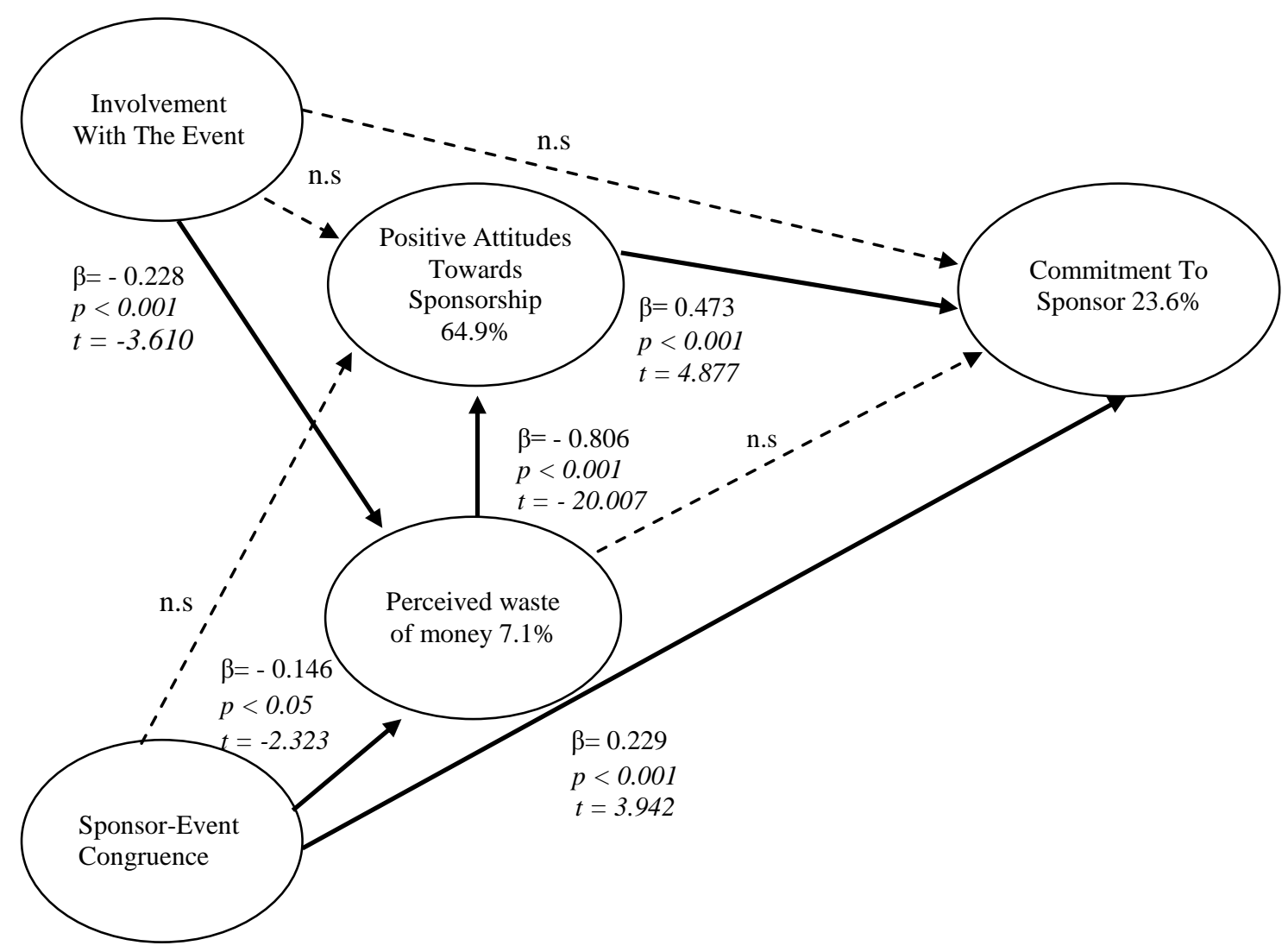

Figure 2: Research Hypotheses Validation

\section{Discussion}

This study makes several important contributions to theory and carries managerial implications which are discussed next.

The majority of studies investigate the effectiveness of sponsorship activities in reaching commercial objectives, such as enhanced brand image and recall (e.g. Cliffe \& Motion, 2005; Cornwell et al., 2006; Jagre et al., 2001). However, the literature also suggests that the setting and reaching of relational objectives, such as the development of goodwill and positive relationships with important stakeholder groups, is increasingly important in order to achieve organisational long-term success (Dean, 2002; Lacey et al., 2010; Madill \& O'Reilly, 2010). This notion is in line with neo-institutional theory, which suggests that due to resource dependence, organisations need to achieve acceptance amongst larger publics in order to gain support through a variety of means (Hillebrand et al., 
2011; Meyer \& Rowan, 1977; Suddaby \& Greenwood, 2005). The idea is consistent with other theoretical frameworks, such as relationship marketing, and has lately also gained some attention in the sponsorship literature. Nonetheless, to date little research investigates the effectiveness of sponsorship in reaching non-economic organisational objectives. To address this gap in the literature, this study assessed through which mechanisms events sponsorship contributes to commitment towards an organisation, in particular citizen commitment towards a public sector body.

In particular, our study contributes to theory as it looks at the phenomenon from the perspective of the public sector body as the sponsor, rather than the sponsored entity. Moreover, it assess which factors impact on the development of commitment towards the sponsor, rather than the sponsored event. The estimation of the sponsorship model as investigated in this study demonstrates that directly or indirectly 1) positive attitudes towards the sponsorship activity, 2) perceived waste of financial resources, as well as 3) perceived event-sponsor congruence significantly impact on commitment to the sponsor. Comparing the three effects, the study contributes the extant literature by showing that it is of utmost importance for public sponsors to develop positive attitudes towards the sponsorship activity. They have a significantly stronger impact on commitment than perceived event-sponsor congruence or perceived waste of financial resources - which impacts strongly but indirectly the commitment towards the sponsor. These findings suggest a rational model of sponsorship effectiveness and support congruence theoretical considerations (Cornwell et al., 2006; Filis \& Spais, 2012; Simmons \& Becker-Olsen, 2006; Sohn \& Han, 2012; Olson \& Thjømøe, 2011; Woisetschlaeger \& Michaelis, 2012): while involvement with the sponsored entity has no impact on sponsor commitment, rational considerations, such as positive attitude formation towards the sponsorship activity, and to a lesser extent perceived waste of financial resources or event-sponsor congruence, play a significant role in the commitment formation towards the public sponsor. By far, the strongest determinant of commitment are the positive attitude towards the sponsorship activity, in other words the belief that public sponsorship is seen as beneficial for the region by the participants at the event. Furthermore, the results indicate that positive attitudes towards the sponsorship are primarily and highly dependent on whether citizens perceive the sponsorship activity to be a waste of financial resources. Recall that the public administration literature suggests that public sector bodies are often judged by their input into activities, rather than the output (Kearsy \& Varey, 1998). Indeed, this finding corroborates the idea that sponsorship activities with relational objectives are elaborated on the rational and normative belief whether tax money should be used or not to sponsor an event.

\section{CONCLUSION}

As public sector organisations are under immense pressure to establish and maintain good relations with important stakeholder groups, such as their electorate (McNulty \& Ferlie, 2004; Osborne \& Gaebler, 1992; Sanger, 2008), as well as the fact that the public sector is increasingly investing resources into the support of local events such as concerts and sports events (Walliser, 2006), the effectiveness of sponsorship activities in public sector contexts is important to investigate from a public administration perspective. In relation to the above results, public management needs to further emphasise the implementation of programs that reduce citizens' belief that the support of professional sport events could represent a perceived waste of public resources. The results of this study provide guidance on how this aim can be achieved.

Public sector bodies should make sure that citizens believe that it is appropriate to financially support a certain event. Focusing on the sponsorship model in particular, the findings suggest that public sector bodies should pay specifically attention to the explicit communication of the reasons for the sponsorship activity. Pursuing this perceived event-sponsor congruence is important (Simmons \& Becker-Olsen, 2006) due to its direct impact on commitment, as well as its indirect impact through its influence on positive attitudes towards the sponsorship activity. Also, perceived event-sponsor congruence reduces perceptions that the sponsorship is a waste of taxpayers' money. However, public sector bodies do not have many natural fits with events. Thus, the rationale for sponsorship activities needs to be explicitly demonstrated in order to positively influence evaluations and ultimately enhance their effectiveness (Cornwell et al., 2006). This is particularly the case for older citizens, as our results suggest that they perceive the association between the public sponsor and the sport event as being less compatible. This aim could be achieved through messages related to health improvement in the case of sport events, cultural support in terms of music festivals, or economic development related to business events such as conferences and trade shows. 


\section{Limitations And Directions For Future Research}

This study deployed survey research in a real-life sponsorship context. Many studies in this field of research use experimental designs, often with student samples. While the experimental approach is criticised for lacking external validity, the field approach also has some disadvantages. In the main, the limitations of this study lie in the convenience sampling method at the time of the fieldwork during the event. The data collection focused on one particular event and the resulting sample size is relatively small. Therefore, future research should look at a wider range of events and across different sectors in order to assess the validity of the findings. Such an approach adds to the understanding in what respect the sponsorship model and its underlying dynamics may be similar or different across sectors. For example, further research could investigate whether across public sector contexts audiences assess sponsorship activities more rationally than in private sector settings. Further, our investigation focused on the achievement of one particular relational objective through sponsorship, namely the commitment to the sponsor. Future research could assess to what extent the links in the sponsorship model vary, depending on whether the sponsorship is relational or commercial in nature.

\section{AUTHOR INFORMATION}

\section{Barbara Caemmerer}

Before joining ESSCA, Paris, as a Professor, Barbara worked for several years in the Department of Marketing at the University of Strathclyde, Glasgow, where she also earned her PhD. Her research focuses on services marketing and management and has been funded by a variety of private and public sector organisations.

\section{Raluca Mogos Descotes}

Raluca Mogos Descotes works as an Assistant Professor of Marketing at Lorraine University, CEREFIGE Research Center. Her main research interests are SMEs' export performance, institutional theory and public sponsorship.

\section{REFERENCES}

1. Antioco, M., Moenaert, R., Feinberg, R. and Wetzels, M. (2008), "Integrating service and design: the influences of organizational and communication factors on relative product and service characteristics", Journal of the Academy of Marketing Science, Vol. 36, No. 4, pp. 501-521.

2. Bansal H. S., Irving P. G. and Taylor, S. F. (2004), “A three-component model of customer commitment to service providers", Journal of the Academy of Marketing Science, Vol. 32, No. 3, pp. 234-250.

3. Barclay, D. W., Higgins, C. A. and Thompson, R. L. (1995), "The partial least squares approach to causal modeling: personal computer adoption and use as illustration", Technology Studies, Vol. 2, No. 2, 285-309.

4. Chien, P. M., Cornwell, B. T. and Pappu, R. (2011), "Sponsorship portfolio as a brand-image creation strategy", Journal of Business Research, Vol. 64, No. 2, pp. 142-149.

5. Chin, W. W. (1998), "The partial least squares approach to structural equation modeling”, in Modern Methods for Business Research, (Ed.) George A. Marcoulides, New Jersey, Lawrence Erlbaum Associates.

6. Cliffe, S. J. and Motion J. (2005), "Building contemporary brands: a sponsorship-based strategy", Journal of Business Research, Vol. 58, No. 8, pp. 1068-1077.

7. Cohen, J. (1988), Statistical Power Analysis for the Behavioral Sciences, New Jersey, Lawrence Erlbaum.

8. Coppetti, C., Wentzel, D., Tomczak, T. and Henkel, S. (2009), "Improving incongruent sponsorships through articulation of the sponsorship and audience participation", Journal of Marketing Communications, Vol. 15, No. 1, pp. 17-34.

9. Cornwell, B. T., Weeks, C. S. and Roy, D. P. (2005), "Sponsorship-linked marketing: opening the black box", Journal of Advertising, Vol. 34, No. 2, pp. 21-42.

10. Cornwell, B. T. and Coote L. V. (2005), "Corporate sponsorship of a cause: the role of identification in purchase intent”, Journal of Business Research, Vol. 58, No. 3, pp. 268-276.

11. Cornwell, B. T., Humphreys, M. S., Maguire, A. M, Weeks, C. S. and Tellegen, C. L. (2006), "Sponsorship-linked marketing: the Role of articulation in memory", Journal of Consumer Research, Vol. 33, No. 3, pp. 312-321.

12. Dalakas, V. and Levin, A. M. (2005), "The balance theory domino: how sponsorships may elicit negative consumer attitudes", Advances in Consumer Research, Vol. 32, No. 1, pp. 91-97. 
13. Dean, D. (2002), "Associating the corporation with a charitable event through sponsorship: measuring the effects of corporate community relations", Journal of Advertising, Vol. 31, No. 4, pp. 77-87.

14. Deephouse, D. L and Carter, S. M. (2005), "An examination of differences between organizational legitimacy and organizational reputation", Journal of Management Studies, Vol. 42, No. 2, pp. 329-360.

15. Farrelly, F. and Quester, P. (2003), "The effects of market orientation on trust and commitment: The case of the sponsorship business-to-business relationship", European Journal of Marketing, Vol. 37, No. 3/4, pp. 530-553.

16. Ferrell, O. C. and Ferrell L. (2008), “A macromarketing ethics framework: stakeholder orientation and distributive justice", Journal of Macromarketing, Vol. 28, No. 1, pp. 24-32.

17. Filis, G. and Spais, G. (2012), "The effect of sport sponsorship programs of various sport events on stock price behavior during a sport event", Journal of Promotion Management, Vol. 18, No. 1, pp. 3-41.

18. Fullerton, G. L. (2003), "When does commitment lead to loyalty?", Journal of Service Research, Vol. 5, No. 4, pp. 333-344.

19. Fornell, C. and Bookstein, F. L. (1982), "Two structural equation models: LISREL and PLS applied to consumer exit-voice theory", Journal of Marketing Research, Vol. 19, No. 4, pp. 440-453.

20. Fornell, C. and Larcker, D. F. (1981), "Evaluating structural equation models with unobservable variables and measurement error", Journal of Marketing Research, Vol. 18, No. 1, pp. 39-50.

21. Garson, D. J. (2012), "Testing Statistical Assumptions", North Carolina: Statistical Associates Publishing.

22. Grewal, R., J. A. Cote and H. Baumgartner (2004), "Multicollinearity and measurement error in structural equation models: implications for theory testing", Marketing Science, Vol. 23, No. 4, pp. 519-529.

23. Grönroos C. (1989), "Defining marketing: a market-oriented approach", European Journal of Marketing, Vol. 23, No. 1, pp. 52-60.

24. Gustafsson, A., Johnson, M. D. and Roos, I. (2005), "The effects of customer satisfaction, relationship commitment dimensions, and triggers on customer retention", Journal of Marketing, Vol. 69, No. 4, pp. 210-218.

25. Gwinner, K. (1997), “A model of image creation and image transfer in event sponsorship", International Marketing Review, Vol. 14, No. 3, pp. 145-158.

26. Hall, D. T. (1979), Organizational Commitment: Theory, Research, and Measurement, Northwestern University.

27. Hattula, S., Hammerschmidt, M., Hattula, J., Bauer, H. (2011), "Sport sponsorship and brand equity: exploring the dynamic relationship between brand equity and sport-related success in sport clubs", AMA Summer Educators' Conference, Vol. 22, p. 5-6.

28. Hennig-Thurau, T., Gwinner, K. R. and Gremler, D. D. (2002), "Understanding relationship marketing outcomes?", Journal of Service Research, Vol. 4, No. 3, pp. 230-247.

29. Herrmann, J.-L., Walliser, B., and Kacha, M. (2011), "Consumer consideration of sponsor brands they do not remember - Taking a wider look at the memorisation effects of sponsorship", International Journal of Advertising, Vol. 30, No. 2, pp. 259-281.

30. Heskett, J. L., Jones, T. O., Loveman, G. W., Sasser, W. E. and Schlesinger, L. (1994), "Putting the service-profit chain to work", Harvard Business Review, (March-April), pp. 164-174.

31. Hillebrand, B., Nijholt, J. and Nijssen, E. (2011), "Exploring CRM effectiveness: an institutional theory perspective", Journal of the Academy of Marketing Science, Vol. 39, No. 4, pp. 592-608.

32. International Events Group (IEG) (2013) IEG Sponsorship Report. Available online at: http://www.sponsorship.com/iegsr/2013/01/07/2013-Sponsorship-Outlook--Spending-Increase-Is-Dou.aspx (accessed June 2014).

33. Jagre, E., Watson, J.J. and Watson, J. G. (2001), "Sponsorship and congruity theory: a theoretical framework for explaining consumer attitude and recall of event sponsorship", Advances in Consumer Research, Vol. 28, No. 1, pp. 439-445.

34. Kapferer, J.-N. and Laurent, G. (1993), "Further evidence on the consumer involvement profile: Five antecedents of involvement", Psychology \& Marketing, Vol. 10, No. 4, pp. 347-355.

35. Lacey, R., Close, A. G. and Finney, R. Z. (2010), "The pivotal roles of product knowledge and corporate social responsibility in event sponsorship effectiveness", Journal of Business Research, Vol. 63, No. 11, pp. $1222-1228$.

36. Madill, J., and O'Reilly, N. (2010), "Investigating social marketing sponsorships: Terminology, stakeholders, and objectives”, Journal of Business Research, Vol. 63, No. 2, pp. 133-139. 
37. Matthews, J., and Shulman, A. D. (2005), "Competitive advantage in public-sector organizations: explaining the public good/sustainable competitive advantage paradox", Journal of Business Research, Vol. 58, No. 2, pp. 232-240.

38. McCarville, R., and Copeland, R. (1994), "Understanding sport sponsorship through exchange theory", Journal of Sport Management, Vol. 8, No. 2, pp. 102-114.

39. McNulty, T. and Ferlie, E. (2004), "Process transformation: limitations to radical organizational change within public service organizations", Organization Studies, Vol. 25, No. 8, pp. 1389-1412.

40. Meenaghan, J.A. (1983), “Commercial sponsorship”, European Journal of Marketing, Vol. 17, No. 7, pp. 5-73.

41. Meenaghan, T. (1991), "The role of sponsorship in the marketing communications mix", International Journal of Advertising, Vol. 10, No. 1, pp. 35-47.

42. Meenaghan, T. (2001), "Understanding sponsorship effects", Psychology \& Marketing, Vol. 18, No. 2, pp. 95-122.

43. Meyer, J. W. and Rowan, B. (1977), "Institutionalized organizations: formal structure as myth and ceremony", The American Journal of Sociology, Vol. 83, No. 3, pp. 340-363.

44. Mowen, A., Kyle, G., Jackowski, M. (2007), "Citizen preferences for the corporate sponsorship of public sector park and recreation organizations", Journal of Nonprofit and Public Sector Marketing, Vol. 18, No. 2, pp. 93-118.

45. Ngan, H., Prendergast, G. and Tsang, E. (2011), "Linking sports sponsorship with purchase intentions: Team performance, stars, and the moderating role of team identification", European Journal of Marketing, Vol. 45, No. 4, pp. 551-556.

46. Nicholls, J.A.F., Roslow, and S. Laskey, H. A. (1994), "Sports event sponsorship for brand promotion", Journal of Applied Business Research, Vol. 10, No. 4, pp. 35-40.

47. Nunally, J. C. and Bernstein, I. H. (1994), Psychometric Theory, New York, McGraw-Hill.

48. Olson, E. L. (2010), "Does sponsorship work in the same way in different sponsorship contexts?", European Journal of Marketing, Vol. 44, No. 1/2, pp. 180-199.

49. Olson, E. L. and Thjømøe, H. M. (2011), Explaining and articulating the fit construct in sponsorship", Journal of Advertising, Vol. 40, No. 1, pp. 57-70.

50. Osborne, D. and Gaebler, T. (1992), Reinventing Government: How the Entrepreneurial Spirit is Transforming the Public Sector, Reading, MA, Addison-Wesley.

51. Pope, N., Voges, K. E. and Brown, M. (2009), "Winning ways - immediate and long-term effects of sponsorship on perceptions of brand quality and corporate image", Journal of Advertising, Vol. 38, No. 2, pp. 5-20.

52. Porter, L. W., Steers, R. M., Mowday, R. T. and Boulian, P. V. (1974), “Organizational commitment, job satisfaction, and turnover among psychiatric technicians”, Journal of Applied Psychology, Vol. 59, pp. 603-609.

53. Rifon, N. J., Choi, S. M., Trimble, C. S. and Li, H. (2004), "Congruence effects in sponsorship - the mediating role of sponsor credibility and consumer attributions of sponsor motive", Journal of Advertising, Vol. 33, No. 1, pp. 29-42.

54. Roy, D. P. and Cornwell, B. T. (2004), "The effects of consumer knowledge on responses to event sponsorship", Psychology \& Marketing, Vol. 21, No. 3, pp. 185-207.

55. Roussel, P., F. Durrieu F., Campoy E. and A. El Akremi (2002), "Méthodes d'équations structurelles: recherche et applications en gestion”, Economica: Paris.

56. Sohn, Y. S. and Han, J. K. (2012), "Communication strategies for enhancing perceived fit in the CSR sponsorship context", International Journal of Advertising, Vol. 31, No. 1, pp. 133-146.

57. Sabadie, W. (2003), "Conceptualisation et mesure de la qualité d'un service publique", Recherche et Applications en Marketing, Vol. 18, No. 1, pp. 1-24.

58. Sanger, M. B. (2008), "From measurement to management: breaking through the barriers to state and local performance", Public Administration Review, Vol.68, No. 6, pp. 70-85.

Sharma, N. and Patterson, P. G. (2000), "Switching costs, alternative attractiveness and experience as moderators of relationship commitment in professional, consumer services?", International Journal of Service Industry Management, Vol. 11, No. 5, pp. 470-490.

60. Simmons, C. J. and Becker-Olsen, K. L. (2006), “Achieving marketing objectives through social sponsorship”, Journal of Marketing, Vol. 70, No. 4, pp. 154-169. 
61. Sirgy, M. J., Lee, D. J., Johar, J. S. and Tidwell, T. (2008), "Effect of self-congruity with sponsorship on brand loyalty", Journal of Business Research, Vol. 61, No. 10, pp. 1091-1097.

62. Speed, R. and Thompson, P. (2000), "Determinants of sports sponsorship response", Journal of the Academy of Marketing Science, Vol. 28, No. 2, pp. 226-238.

63. Suchman, M. C. (1995), "Managing legitimacy: strategic and institutional approaches", Academy of Management Review, Vol. 20, No. 3, pp. 571-610.

64. Suddaby, R. and Greenwood, R. (2005), "Rhetorical strategies of legitimacy", Administrative Science Quarterly, Vol. 50, No. 1, pp. 35-67.

65. Tenenhaus, M., Vinzi, V. E., Chatelin, Y. M. and Lauro, C. (2005), "PLS path modeling", Computational Statistics \& Data Analysis, Vol. 48, No. 1, pp. 159-205.

66. Vergne, J. P. (2011), "Toward a new measure of organizational legitimacy: method, validation and illustration", Organizational Research Methods, Vol. 14, No. 3, pp. 484-502.

67. Voss, K. E., Spangenberg, E. R. and Grohmann, B. (2003), "Measuring the hedonic and utilitarian dimensions of consumer attitude", Journal of Marketing Research, Vol. 40, (August), pp. 310-320.

68. Walliser, B. (2006), Le Parrainage: Sponsoring et Mécénat, Paris, Dunod.

69. Walliser, B., Mathieu, K., and Mogos Descotes, R. (2005), "Legitimizing public authorities as sponsors: an inquiry into the factors related to the perception and the memorization of their sponsorship", International Review of Public and Non Profit Marketing, Vol. 2, No. 1, pp. 51-58.

70. White, S. and Schneider, B. (2000), "Climbing the commitment ladder: the role of expectations disconfirmation on customers' behavioral intentions", Journal of Service Research, Vol. 2, No. 3, pp. 240253.

71. Wold, H. (1980), "Model construction and evaluation when theoretical knowledge is scarce",

72. In J. Kmenta, \& J. B. Ramsey (Eds.), Evaluation of Econometric Models, pp. 47-74.

73. Woisetschlaeger, D. and Michaelis, M. (2012), "Sponsorship congruence and brand image - a pre- post event analysis", European Journal of Marketing, Vol. 46, No. 3/4, pp. 509-523.

74. Zdravkovic, S. and Till, B. (2012), "Enhancing brand image via sponsorship - Strength of association effect”, International Journal of Advertising, Vol. 31, No. 1, pp. 113-132. 


\section{NOTES}

